International Journal of Civil Engineering and Technology (IJCIET)

Volume 9, Issue 10, October 2018, pp. 1465-1472, Article ID: IJCIET_09_10_146

Available online at http://www.iaeme.com/ijciet/issues.asp?JType=IJCIET\&VType=9\&IType=10

ISSN Print: 0976-6308 and ISSN Online: 0976-6316

CIAEME Publication

Scopus Indexed

\title{
THE DEVELOPMENT OF COMPRESSIVE STRENGTH ON GEOPOLYMER MORTAR USING FLY ASH AS BASED MATERIAL IN SOUTH SULAWESI
}

\author{
Erniati Bachtiar*, Asri Mulya S, Fatmawaty R, Herwina Rahayu Putri \\ Department of Civil Engineering, Fajar University, Makassar, Indonesia
}

\section{Ismail Marzuki, Muhammad Chaerul, Sinardi}

Department of Infrastructure \& Environmental Engineering, Fajar University, Indonesia

* Correspondence Author: erni_nurzaman@yahoo.com

\begin{abstract}
Industry in the production of cement produces the effects of $\mathrm{CO}_{2}$ gas which damage the environment. For this reason, it is necessary to look for partial or complete replacement material with environmentally friendly materials. In Indonesia, especially in South Sulawesi, there is industrial waste fly ash from Steam Power Plants (PLTU) which are rich in silica and aluminum which it does not use optimally. Fly ash contains silica and aluminum which it uses as strong binders through the polymerization process. The research objective was to determine the development of compressive strength of geopolymer mortar with different fly ash bases and different curing methods. The research method used is the experimental method in the laboratory. The technique in making and testing mortar samples refers to SNI 036825-2002. The composition of geopolymer mortar uses a ratio of fly ash: sand of 1: 2.75, and $10 \mathrm{Molar} \mathrm{NaOH}$, the ratio of the $\mathrm{Na}_{2} \mathrm{SiO}_{3}$ with $\mathrm{NaOH}$ is 2, the ratio of the activator with fly ash is 0.3. The results showed that The development of compressive strength values in geopolymer mortar along with increasing age. The amount of compressive strength influenced by the type of fly ash and the curing method performed. Geopolymer mortar base on fly ash A (FAA) and geopolymer mortar based on fly ash $B(F A B)$ have a high compressive strength difference. The difference in compressive strength occurs in both curing variations with the average temperature and with temperature $85^{\circ} \mathrm{C}$.
\end{abstract}

Key words: Compressive Strength, Geopolymer Mortar, Fly Ash, Coal.

Cite this Article: Erniati Bachtiar, Asri Mulya, Fatmawaty R, Herwina Rahayu Putri, Ismail Marzuki, Muhammad Chaerul, Sinardi, The Development of Compressive Strength on Geopolymer Mortar Using Fly Ash as Based Material in South Sulawesi, International Journal of Civil Engineering and Technology (IJCIET) 9(10), 2018, pp. 1465-1472. http://www.iaeme.com/IJCIET/issues.asp?JType=IJCIET\&VType=9\&IType=10 


\section{INTRODUCTION}

Mortar is a mixture consisting of several materials namely fine aggregate, binder, and water. Mortar functions as a binding matrix for the constituent parts of construction both structural and non-structural. Implementation of building in the field, people still tend to remain unchanged, where they still use cement as the primary binding material. Eventhow, They know that the use of adhesive in construction has recently drawn criticism because of the effects of the cement industry which produces $\mathrm{CO}_{2}$ gas. $\mathrm{CO}_{2}$ gas is known for greenhouse gas emissions produced by industry during the cement production process. Also, the reduction in the use of cement in construction is also one of 17 sustainable development goals (SDGs) as a global development agreement namely Industry, Innovation, and Infrastructure. Realize sustainable urban development based on environmentally friendly; one way is to reduce the use of cement in construction work by utilizing renewable resources that can replace the function of cement. Alternative cement substitutes needed in the preparation of mortar. The reduction in the use of cement was thought by concrete technology research experts to start researching by replacing cement material as a whole with fly ash materials that use geopolymer bonds. Geopolymer defined as material produced from polymeric and alkalisilicate aluminosilicate geo synthesis which produces tetrahedral-bound $\mathrm{SiO}_{4}$ and $\mathrm{AlO}_{4}$ polymer frameworks [1].

Geopolymers can use the main ingredients of industrial waste, namely fly ash which is rich in Alumina (Al) and Silica (Si) elements. Silica and Alumina elements contained in fly ash dissolved with an alkaline solution called alkaline solution. The alkali solution used is a mixture of Sodium Hydroxide $(\mathrm{NaOH})$, Sodium Silicate $\left(\mathrm{Na}_{2} \mathrm{SiO}_{3}\right)$ and Water Distillate $\left(\mathrm{H}_{2} \mathrm{O}\right)$ which each component has an essential role in synthesis. Geopolymer concrete synthesis is highly dependent on the initial material conditions, namely the nature and composition of fly ash, the concentration of alkaline solution and the geo polymerization process [2]

Fly ash is the residues produced from burning coal which consists of fine particles. Fly ash, also known as fly ash, is one of the industrial wastes from the Steam Power Plant (PLTU) which is rich in silica and aluminum which can use as a sturdy binder through the polymerization process. The elements dissolve of silica and aluminum, and allow the occurrence of chemical reactions; the solution is alkaline. South Sulawesi Province itself has several coal-fired power plants. PLTU annually produces a lot of fly ash or fly ash waste. So that the amount of garbage produced raises the problem that arises is how to use so that trash cannot pollute the environment around us and can be used primarily in the construction world. Because of these problems, so that every year research on construction that is environmentally friendly, especially those that use fly ash waste as a substitute material.

Nowadays geopolymers with fly ash as their primary material can be one of the alternative cement replacement binders that are very potent in the field of building materials and construction [3, 4]. Mortar Geopolymer is a type of mortar material for development that does not use cement, where mortar/concrete geopolymer formed from chemical reactions rather than hydration reactions such as mortar/concrete ordinary [1]. The type of activator used in making mortar/concrete geopolymer adjusted to the compounds contained fly ash, and the composition must be precise so that chemical reactions can occur. Commonly used activators are $8 \mathrm{M}$ to $14 \mathrm{M}$ Sodium Hydroxide and the ratio of Sodium Silicate $\left(\mathrm{Na}_{2} \mathrm{SiO}_{3}\right)$ with Sodium Hydroxide $(\mathrm{NaOH})$ between 0.4 to 2.5 [5]. Geopolymers exhibit many excellent properties such as high strength, low shrinkage, good acid resistance, and low creep[4].

The chemicals most commonly used as activators in the manufacture of geopolymers are $\mathrm{NaOH}, \mathrm{NaSO}$, and $\mathrm{Na}_{2} \mathrm{SiO}_{3}$ [6-8]. Where, The combination of Sodium Silicate $\left(\mathrm{Na}_{2} \mathrm{SiO}_{3}\right)$ and $\mathrm{NaOH}$ produces the best compressive strength $[9,10]$. 
Temuujin et all (2010) has examined geopolymer mortar with the primary material, where the weight ratio of sand to binders varied from 1-9. The results of the study show that geopolymer binders show strong bonds with sand aggregates. The sand content increased without the number of activators is also increased so that it can lead to a decreased geo polymerization rate in the binder system[11].

\section{RESEARCH METHODS}

\subsection{Material}

The material used in the making of geopolymer mortar samples were fly ash, activator, sand, and water.

\section{Fly ash}

Fly ash used in this research is local material. Fly ash obtained from the Steam Power Plant (PLTU) in South Sulawesi. Fly ash derived from two different places. Fly ash gave the name fly ash A (FAA) and B (FAB). Physically the color is light brown and fine-grained like cement. This research is part of the previous study (Erniati B et al., 2018), where fly ash characteristic using X-Ray Fluorescence (XRF) analysis shown in Table 1. Table 1 shows that the highest four chemical compositions of Fly ash among other elements are silicates $\left(\mathrm{SiO}_{2}\right)$, aluminum $\left(\mathrm{Al}_{2} \mathrm{O}_{3}\right)$, ferum $\left(\mathrm{Fe}_{2} \mathrm{O}_{3}\right)$ and Calx lime $(\mathrm{CaO})$. According to SNI 15-2049-2004 that portland cement clinker consists of four main oxide elements namely lime, silica, alumina, and iron oxide. Thus the waste from the burning of PLTU A and PLTU B in South Sulawesi can be used as a substitute for cement because it contains lime, silica, alumina and iron oxide.

Table 1 The composition of fly ash as determined by XRF (Erniati B. et al., 2018)

\begin{tabular}{|l|c|c|c|c|c|c|c|c|}
\hline Composition & $\mathrm{SiO}_{2}$ & $\mathrm{Al}_{2} \mathrm{O}_{3}$ & $\mathrm{Fe}_{2} \mathrm{O}_{3}$ & $\mathrm{CaO}$ & $\mathrm{K}_{2} \mathrm{O}$ & $\mathrm{BaO}$ & $\mathrm{TiO}_{2}$ & $\mathrm{ZrO}_{2}$ \\
\hline FAA (\%) & 35.88 & 9.23 & 29.20 & 23.52 & 1.03 & 0.27 & 0.71 & 0.054 \\
\hline FAB (\%) & 41.45 & 11.06 & 25.28 & 16.19 & 1.35 & 0.136 & 1.05 & 3.16 \\
\hline
\end{tabular}

Based on ASTM C 618-96, fly ash A (FA-A) and fly ash B (FA-B) are class C types, where the $\mathrm{CaO}$ content is $23.52 \%$ and $16.19 \%$ respectively. Fly Ash of FAA and FAB has pozzolanic properties, besides that it is cement. This caused by the high content of $\mathrm{CaO}$ on the fly ash FAA and FAB.

\section{Activator}

Activators are additive materials using for the binding process in the manufacture of fly ash geopolymer mortars. Activators used in this study were Sodium Silicate $\left(\mathrm{Na}_{2} \mathrm{SiO}_{3}\right)$ and Sodium Hydroxide $(\mathrm{NaOH})$.

\section{Air}

In making activators used water

\section{Fine aggregate/Sand}

The fine aggregate used is local sand obtained from local building materials stores. This material is a natural aggregate in Takalar district. This fine aggregate is one of the filling materials for mortar samples. Fine aggregate categorized as coarse gradation with a surface dry weight of 2.76 .

\subsection{Experimental Program}

The research method used is the experimental method in the laboratory. The technique in making and testing mortar samples refers to SNI 03-6825-2002 Method of compressive strength testing of Portland cement mortar for civil works. Especially for the activator 
composition both the molarity and alkaline modulus apply to the results of previous studies. 10 Molar uses the concentration of the solution (Molarity) of $\mathrm{NaOH}$ is a unit of attention or concentration of a solution, in other words, the material of molarity is the amount of solute in one liter of solution. The concentration of the answer is the amount of solute contained in a certain amount of solvent or the amount of a particular solution. The ratio of Sodium Silicate $\left(\mathrm{Na}_{2} \mathrm{SiO}_{3}\right)$ to Sodium Hydroxide $(\mathrm{NaOH})$ used is 2 . The ratio of fly ash to sand is 1: 2.75 . Before the mixed design, the characterization of the constituent materials was carried out, namely the characterization of sand and fly ash. For sand characterization, there are several types of inspection based on SNI, namely sludge, organic content, specific gravity and absorption, filter analysis, volume weight, and moisture content. For fly ash, chemical tests were carried out using X-Ray Fluorescence (XRF) analysis. This XRF analysis aims to determine the chemical content of fly ash. The test specimens used are in the form of cubes with a size of $5 \times 5 \times 5 \mathrm{~cm}$. Compressive strength testing was carried out on samples after seven days, 14 days, 28 days and 56 days. The compressive strength test using the Compression Testing Machine (UTM) is obtained at the maximum load, i.e., when the mortar is destroyed receiving the pressure (Pmax). Then the compressive strength can be calculated using the maximum capacity $(\mathrm{P})$ divided by the sample surface area $(\mathrm{A})$.

Variation in the sample consisted of the type of fly ash, age and curing method. Kind of fly ash divided into two based on the location of the acquisition of fly ash, namely, fly ash A (A) and fly ash B (B), the curing method consists of two curing with normal temperature about $25^{\circ} \mathrm{C}(\mathrm{CA})$ and curing with a temperature of $85^{\circ} \mathrm{C}$ (T_85). Samples were named based on the type of fly ash namely the Mortar Geopolymer base of fly ash A given the name FAA, and Mortar Geopolymer base of fly ash B which it gave the name FAB. Compressive strength testing was carried out on samples after seven days, 14 days, 28 days and 56 days.

\section{RESULT AND DISCUSSION}

\subsection{Relation of the compressive strength and age on the geopolymer mortar}

Fly ash is a cement substitute that functions as a binder in geopolymer mortar. Research on the development of compressive strength of geopolymer mortar using fly ash from 2 (two) different places seen in Fig. 1 and Fig. 2.

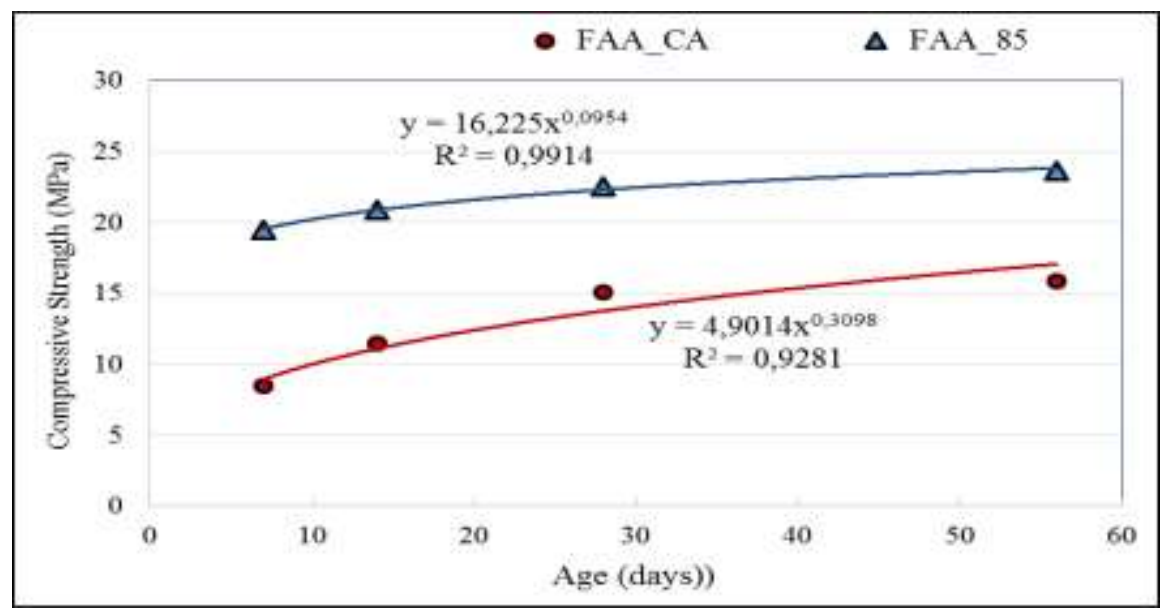

FAA_CA: Sample of Geopolymer Mortar based Fly ash A with cured air

FAA_85: Sample of Geopolymer Mortar based Fly ash A with cured temperature $85^{\circ} \mathrm{C}$

Figure 1 The compressive strength development of geopolymer mortar based fly ash A 
Fig. 1 shows the compressive strength development of mortar geopolymers using fly ash A (FAA). Fig. 1, it can be seen that geopolymer mortar based fly ash A cured of air and geopolymer mortar based fly ash A cured of a temperature $85^{\circ} \mathrm{C}$, both of which have an increase of compressive strength as age increases. Also, Fig.1 shows the correlation between the compressive strength and age of geopolymer mortar. Geopolymer mortar based fly ash A cured of the air have a nonlinear equation: $y=4,9014 \mathrm{x}^{0,3098}$ and $\mathrm{R}^{2}=0,9281$. Geopolymer mortar based fly ash $\mathrm{A}$ cured of a temperature of $85^{\circ} \mathrm{C}$ have a nonlinear equation: $\mathrm{y}=16,225 \mathrm{x}^{0,0954}$ and $\mathrm{R}^{2}=0,9914$. By looking at the coefficient value of $\mathrm{R}^{2}$, it concluded that the compressive strength value and age has a significant relationship.

Fig. 2 shows the compressive strength development of mortar geopolymers using fly ash B (FAB). Fig. 1, it can be seen that the geopolymer mortar base fly ash B cured of air and the geopolymer mortar base fly ash $\mathrm{B}$ cured of a temperature $85^{\circ} \mathrm{C}$, both of which have an increase of compressive strength as age increases. Also, Fig.1 shows the correlation between the compressive strength and age of geopolymer mortar. Geopolymer mortar based fly ash B cured of air have a non linear equation: $\mathrm{y}=3,2082 \mathrm{x}^{0,1323}$ and $\mathrm{R}^{2}=0,9923$. Geopolymer mortar based fly ash $\mathrm{A}$ cured of a temperature of $85^{\circ} \mathrm{C}$ have a nonlinear equation: $y=2,3003 x^{0,1508}$ and $R^{2}=0,9503$. By looking at the coefficient value $R^{2}$, it concluded that the compressive strength value and age has a significant relationship.

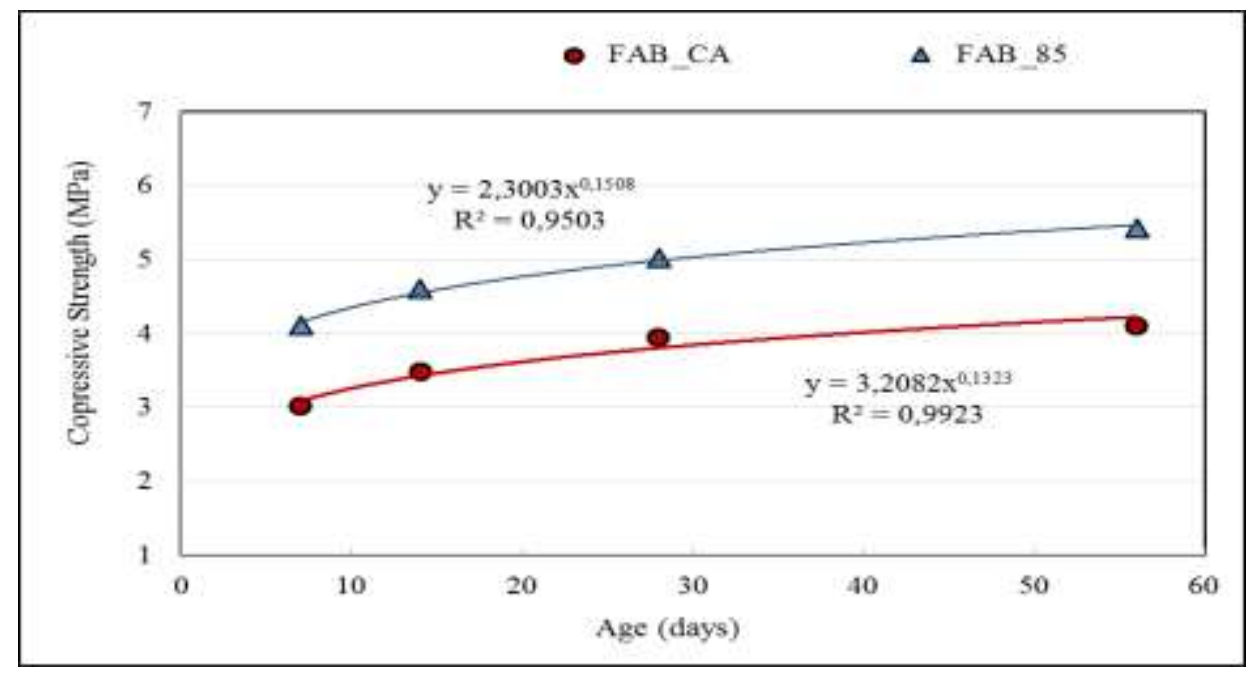

FAB_CU: Sample of Geopolymer Mortar based Fly ash B with cured air

FAB_85: Sample of Geopolymer Mortar based Fly ash B with cured temperature $85^{\circ} \mathrm{C}$

Figure 2 The compressive strength development of geopolymer mortar based fly ash B

\subsection{The comparison of the compressive strength on the geopolymers mortar based on fly ash A and fly ash B}

Geopolymer mortar base on fly ash A (FAA) and geopolymer mortar based on fly ash B (FAB) have a high compressive strength difference. The difference in compressive strength occurs in both cure variations with standard temperature and with temperature (C_85o). The comparison of compressive strength on mortar geopolymer based fly ash A (FAA) and mortar geopolymer based fly ash B (FAB) can see in Fig. 3 and Fig.4.

Fig. 3 shows a comparison between geopolymer mortar samples based on fly ash A and geopolymer mortar based on fly ash $\mathrm{B}$ cure with room temperature around $25^{\circ} \mathrm{C}$. The percentage difference in compressive strength on geopolymer mortar at 7 days, 14 days, 28 days and 56 days was $64.48 \%, 69.70 \%, 73.91 \%$, and $74.15 \%$, respectively. 
Fig. 4 shows a comparison between geopolymer mortar samples based on fly ash A and geopolymer mortar based on fly ash $\mathrm{B}$ curing at a temperature of $85^{\circ} \mathrm{C}$. The percentage difference in compressive strength on geopolymer mortar at 7 days, 14 days, 28 days and 56 days was $78.86 \%, 78.01 \%, 77.73 \%$, and $77.08 \%$ respectively.

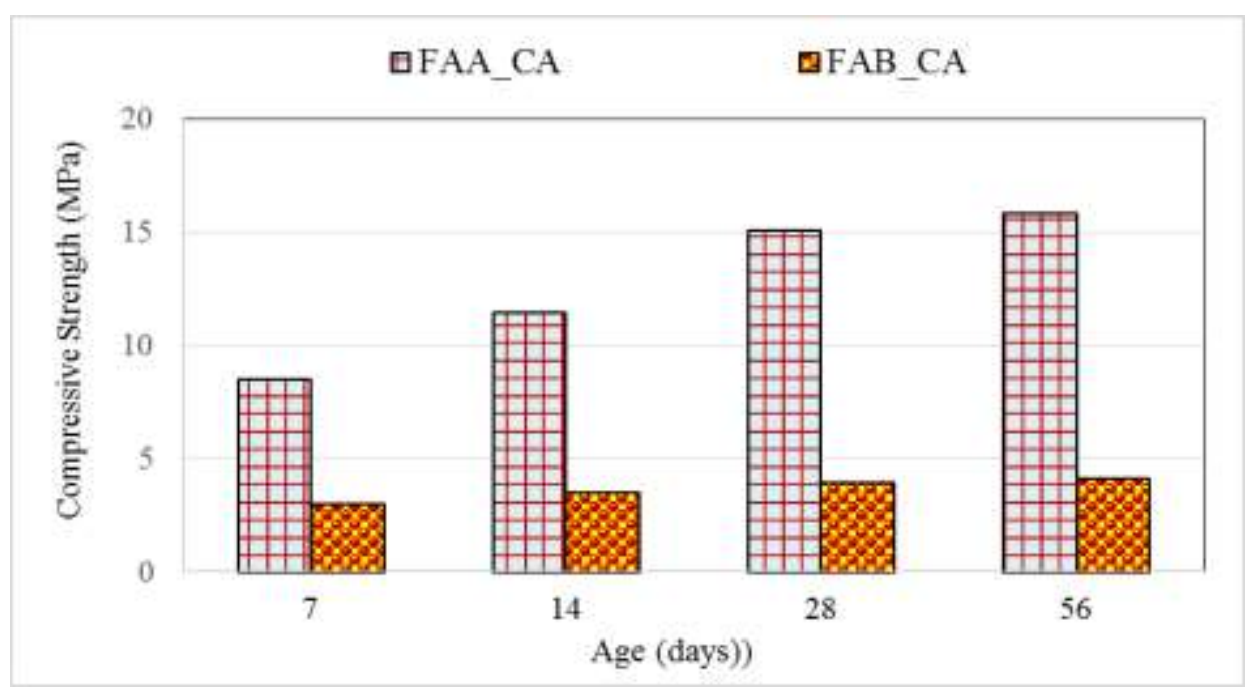

FAA_CU: Sample of Geopolymer Mortar based Fly ash A with cured air FAB_CU: Sample of Geopolymer Mortar based Fly ash B with cured air

Figure 3 The compressive strength of geopolymer mortar cured air

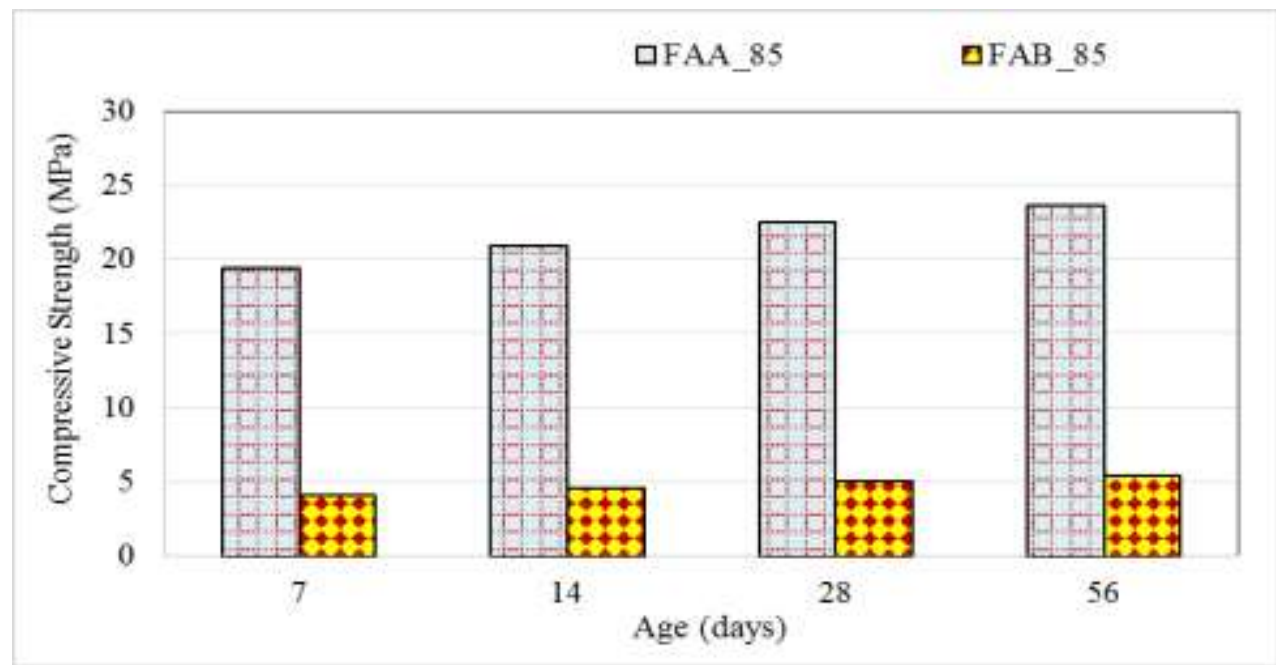

FAA_85: Sample of Geopolymer Mortar based Fly ash A with cured temperature $85^{\circ} \mathrm{C}$ FAB_85: Sample of Geopolymer Mortar based Fly ash B with cured temperature $85^{\circ} \mathrm{C}$

Figure 4 The compressive strength of geopolymer mortar cured temperature $85^{\circ} \mathrm{C}$

Fig. 5 shows the comparison of compressive strength between the geopolymer mortar based on fly ash A and B. The compressive strength of geopolymer mortar based on fly ash A is higher than that of geopolymer mortar based on fly ash B. This occurs in both variations of curing, i.e., curing air temperature (CA) and curing with a temperature of $85^{\circ} \mathrm{C}$ (T_85). In geopolymer mortar base on fly ash A and fly ash B, the sample with curing temperature was $850 \mathrm{C}$ higher than the sample with air curing. Percentage difference in compressive strength on the geopolymer mortar based on fly ash A base due to variations in curing at 28 and 56 of $32.97 \%$ and $32.92 \%$, respectively. The difference percentage of compressive strength in 
geopolymer mortar based on fly ash B due to a variation of curing at the age of 28 and 56 was $21.46 \%$ and $24.35 \%$, respectively. Physically, geopolymer mortar based on fly ash B has a lot of cracks and rather large pores, where the porous is clearly visible. As Erniati et al. 's research on the microstructure of concrete and porosity affects the compressive strength of concrete in other words that the porosity is significant with the mechanical properties of a test object $([12,13])$

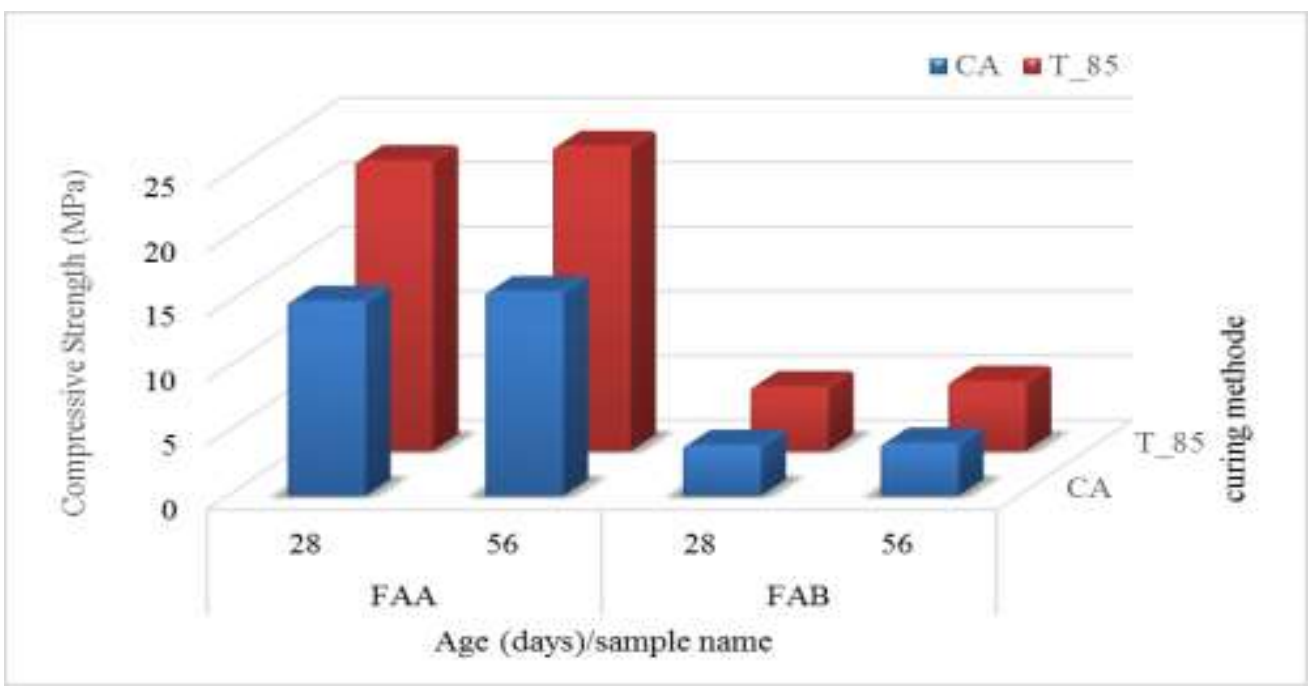

FAA: Sample of Geopolymer Mortar based Fly ash A

FAB: Sample of Geopolymer Mortar based Fly ash B

CA: Curing of Air (Normal temperature about $25^{\circ} \mathrm{C}$

T_85: Curing of temperature $85^{\circ} \mathrm{C}$

Figure 5 The curing variation effect on the geopolymer mortar based fly ash A and B

\section{CONCLUSIONS}

The development of compressive strength values in geopolymer mortar along with increasing age. The amount of compressive strength influence by the type of fly ash and the curing method performed. Geopolymer mortar base on fly ash A (FAA) and geopolymer mortar based on fly ash B (FAB) have a high compressive strength difference. The difference in compressive strength occurs in both curing variations with standard temperature and with temperature $85^{\circ} \mathrm{C}$. Percentage difference in compressive strength on the geopolymer mortar based on fly ash A base due to variations in curing at 28 and 56 of $32.97 \%$ and $32.92 \%$. The difference percentage of compressive strength on geopolymer mortar based on fly ash B due to a variation of curing at the age of 28 and 56 was $21.46 \%$ and $24.35 \%$.

\section{ACKNOWLEDGMENT}

Thank you to the Ministry of Research, Technology and Higher Education (RISTEK DIKTI) with the contract number 1121 / K9 / KT.03 / 2018 which has funded fiscal of Competency Based Research (PBK) in 2018 
The Development of Compressive Strength on Geopolymer Mortar Using Fly Ash as Based Material in South Sulawesi

\section{REFERENCES}

[1] J. Davidovits, In proceedings of Geopolymer '99 International Conferences, France, 1999.

[2] J. Van Jaarsveld, J. Van Deventer, G. Lukey, Chemical Engineering Journal, 89 (2002) 63-73.

[3] G.M. Palomo A, Blanco MT, Cement Concrete Res 29 (1999) 1323-1331.

[4] D. Hardjito, S.E. Wallah, D.M.J. Sumajouw, B.V. Rangan, Australian Journal of Structural Engineering, 6 (2015) 77-85.

[5] H. Wang, H. Li \& F. Yan, Materials Letters, 59 (2005) 3976-3981.

[6] F. Collins, J.G. Sanjayan, Cement and Concrete Research, 28 (1998) 655-664.

[7] S. Song, D. Sohn, H.M.J.T.O. Mason, Journal of Materials, 35 (2000) 249- 257.

[8] L. Yongde, S. Yao, Cement and Concrete Research, 30 (2000) 963-966.

[9] T. Bakharev, Cement and Concrete Research, 35 (2005) 1224-1232.

[10] A. Fernandez-Jimenez, A. Palomo, 35 (2005) 1984-1992.

[11] J. Temuujin, A.v. Riessen, K.J.D. MacKenzie, Construction and Building Materials 24 (2010) 1906-1910.

[12] Erniati, M.W. Tjaronge, Zulharnah, U.R. Irfan, Procedia Engineering, 125 (2015) 832 837.

[13] Erniati, M.W. Tjaronge, R. Djamaluddin, V. Sampebulu, International Journal of Applied Engineering Research, 9 (2014) 18087-18095. 